Ключові слова: господарська діяльність релігійних організацій, господарська компетенція релігійних організаџій, власність релігійних організацій, організаційноправова структура релігійних організачій, канонічне право.

\title{
P.Bochkov \\ RELIGIOUS ORGANIZATIONS AS PARTICIPANTS IN ECONOMIC RELATIONS
}

The article analyzes the features of economic activity of religious organizations and its legal support in modern Ukraine. A range of problematic issues that need further research and legal regulation is outlined.

Keywords: economic activity of religious organizations, economic competence of religious organizations, property of religious organizations, organizational and legal structure of religious organizations, Canon law.

Стаття надійшла до редакції 01.11.2019 р.

УДК 343.13

\section{О. О. Лісовий}

\section{ПОНЯТТЯ ТА СУТНІСТЬ СУДОВОГО КОНТРОЛЮ ПРИ ПРОВЕДЕННІ НСРД, ПОВ’ЯЗАНИХ ІЗ ВИКОРИСТАННЯМ ТЕХНІЧНИХ ЗАСОБІВ}

У статті розглянуто сутність судового контролю при проведенні негласних слідчих (розшукових) дій, пов'язаних із використанням технічних засобів. Крізь призму таких важливих функцій суду як розгляд скарг на рімення, дії (бездіяльність) посадових осіб та органів досудового розслідування, надання дозволів на процесуальних дій, пов'язаних із обтрунтованим обмеженням прав громадян, виділено ключові ознаки категорії «судовий контроль». Серед пов'язаної сукупності кримінально-прочесуальних дефініцій надано авторське визначення судового контролю при проведенні негласних слідчих (розщукових) дій, пов'язаних із використанням технічних засобів.

Ключові слова: кримінальне провадження, негласні слідчі (розшукові) дії, слідчий суддя, суд, судовий контроль, технічні засоби.

DOI 10.34079/2226-3047-2019-9-18-97-105

Постановка проблеми. Суд виступає стабілізуючою силою в системі функціонування механізму державної влади, здатною захистити права i свободи громадян, ефективно оберігати суспільство від небезпечних соціальних конфліктів та явищ. В галузі кримінального судочинства головна роль суду полягає в забезпеченні прав особистості відповідними органами досудового розслідування та їх посадовими особами. Здійснюючи свій внесок у функціонування системи «стримувань і противаг», суд забезпечує професійність і неупередженість у діях сторони обвинувачення під час виконання іiі представниками передбачених кримінально-процесуальним законом процесуальних функцій.

При здійсненні судового контролю за дотриманням законності у кримінальному провадженні робота суду характеризується здатністю активно впливати на дії та рішення 
суб'єктів кримінального процесу. Особливо важливим є здійснення контролю при проведенні негласних слідчих (розшукових) дій (далі - НСРД), пов'язаних із використанням технічних засобів, оскільки вони часто пов'язані 3 обгрунтованим втручанням у приватне життя осіб, тимчасовим обмеженням конституційних прав i свобод громадян.

Аналіз останніх досліджень. Питання отримання доказової та криміналістично значущої в кримінальному судочинстві інформації розглядали О.М. Бандурка, $\begin{array}{lll}\text { Є.А. Доля, } & \text { С.В. Сськов, } \quad \text { В.П. Захаров, Л.М. Лобойко, } & \text { В.З. Лукашевич, }\end{array}$ Є.Д. Лук'янчиков, Д.Й. Никифорчук, В.Л. Ортинський, Д.П. Письменний, М.А. Погорецький, Д.Б. Сергєєва, Є.Д. Скулиш, В.М. Тертишник, Л.Д. Удалова, І.Ф. Хараберюш, Р.М. Шехавцов, М.Є. Шумило та ін.

Проблематику використання технічних засобів під час протидії злочинності, у тому числі в межах проведення НСРД, досліджували В.І. Василинчук, М.Л. Грібов, В.Ю. Калугін, М.В. Корнієнко, Д.Й. Никифорчук, В.Л. Ортинський, .В. Пиріг, Д.Б. Сергєєва, В.М. Тертишник, В.Г. Уваров, І.Ф. Хараберюш, І.Р. Шинкаренко, О.О. Юхно та ін. Дослідженню питань здійснення судового контролю у кримінальному провадженні присвятили свої роботи І.В. Гловюк, М.В. Багрій, В.В. Городовенко, Ю.М. Грошевий, О.В. Кондратьєв, М.А. Макаров, В.І. Маринів, В.В. Назаров, М.А. Погорецький, О.І. Полюхович, В.О. Попелюшко, О.Ю. Татаров, А.Р. Туманянц, Л.Д. Удалова, О.Г. Шило та ін. Кожен із учених зробив важливий внесок у вирішення проблем, що стоять перед сучасним науковим співтовариством. Однак не всі проблемні питання судового контролю за проведенням НСРД охоплені в працях названих авторів. Окрім того на науковому рівні комплексно ще не досліджувалася проблематика судового контролю при проведенні НСРД, пов'язаних із використанням технічних засобів. Недостатня наукова розробленість теорії, а також існуючі проблеми в діяльності органів судового контролю зумовили необхідність розробки сучасних теоретико-правових та організаційних основ здійснення судового контролю при проведенні НСРД, пов'язаних із використанням технічних засобів.

Mета статmi - дослідити сутність судового контролю при проведенні НСРД, пов'язаних із використанням технічних засобів, та надати його авторське визначення. Для досягнення цією мети необхідно вирішити наступні завдання: встановити обсяг поняття (категорії, явища) «судовий контроль при проведенні НСРД, пов'язаних із використанням технічних засобів» через реалізацію таких функцій як розгляд скарг на рішення, дії (бездіяльність) посадових осіб та органів досудового розслідування, надання дозволів на проведення НСРД, а також виділити ключові ознаки категорії «судовий контроль» серед пов'язаної даною сферою сукупності кримінальнопроцесуальних дефініцій.

Виклад основного матеріалу. За етимологічним походженням категорія «судовий контроль» пов'язана 3 більш загальною категорією «контроль», семантика якої передбачає перевірку або спостереження з метою перевірки (від франц. - «controle»), а також протидію чомусь (від лат. - «contra»). Так, В.М. Гаращук слово «контроль» тлумачить як перевірку, а також спостереження з метою перевірки для протидії чомусь небажаному, тобто виявлення, попередження та припинення протиправної поведінки особи [1, с. 62-63]. Однак визначення терміну «судовий контроль» нормативно не закріплено ані в Конституції України, ані в галузевому законодавстві. Відсутність нормативного визначення зумовлює розвиток наукової полеміки у площині розуміння даного терміну в кримінальному судочинстві, а також виникненню багатьох спроб надати його доктринальне тлумачення. Так, на думку М.В. Багрія, у широкому розумінні це діяльність слідчого судді з перевірки, санкціонування або скасування тих 
чи інших рішень, які приймаються компетентними органами. Учений стверджує, що вирішення питань, пов'язаних із законністю проведення НСРД, є однією з форм судового контролю за досудовим розслідуванням кримінального провадження. Разом із тим він зазначає, що слідчий суддя перевіряє насамперед законність правових підстав для проведення НСРД (і лише тих, які можуть бути проведені з дозволу слідчого судді) [2, c. 88].

Певний час у наукових колах існувала думка, що діяльність суду на досудових стадіях кримінального процесу $\epsilon$ різновидом правосуддя, а судовий контроль охоплюється змістом цього терміну як єдиної функції суду в кримінальному провадженні [3, с. 118; 4, с. 258]. Утім існував інший підхід, представники якого наполягали на тому, що за характером виконуваних дій суду, рішення які ним приймаються на досудовому розслідуванні не повинні розглядатися як різновид правосуддя в його класичному розумінні, адже вони не пов'язані 3 вирішенням кримінального провадження по суті. Інакше кажучи, судовий контроль - це окрема функція суду на досудових стадіях кримінального процесу поряд із дозвільною функцією та функцією застосування заходів кримінально-процесуального примусу [5, с. $20 ; 6$, с. $446 ; 7$, с. 4$]$.

Останній підхід, як нам здається, є більш прогресивним і відповідає сучасним уявленням про вказану наукову категорію. Дійсно, функція судового контролю не пов'язана 3 вирішенням питання винуватості або невинуватості особи у вчиненні кримінального правопорушення [8, с. 115]. Тому його не можна характеризувати як специфічну форму правосуддя, здійснювану під час досудового провадження. Твердження щодо віднесення судового контролю до різновидів правосуддя спростовує сам характер НСРД, які проводяться з дозволу слідчого судді [9, с. 167].

Функція судового контролю на досудовому провадженні виступає стабілізуючою силою, покликаною підтримувати паритет між функціями кримінального переслідування й захисту, а також іншими функціями, оскільки здійснюється судом, який в подальшому вирішує кримінальне провадження по суті. Слід враховувати, що судовий контроль як напрям реалізації судової влади та самостійна кримінальнопроцесуальна функція полягає у здійсненні судом системи перевірочних заходів попереджувального, правовідновлюючого характеру, з метою забезпечення законності та обгрунтованості рішень і дій органів досудового розслідування, які обмежують конституційні права і свободи громадян [10, с. 269].

О.В. Кондратьєв зазначає, що судовий контроль полягає у здійсненні судом перевірочних дій, яким притаманний попереджувальний, правовідновлюючий характер, для забезпечення законності та обгрунтованості дій i рішень органів досудового розслідування [11, с. 23]. Подібної точки зору дотримується М.Г. Шавкун, який під судовим контролем за розслідуванням розуміє систему процесуальних дій та судових рішень, направлених на перевірку діяльності органів досудового розслідування, виявлення, аналіз а також усунення порушень кримінально-процесуального закону [12, c. 7].

На думку Д.П. Кисленко, під судовим контролем, який здійснюється в межах розслідування злочинів, слід розуміти передбачену Конституцією та кримінальнопроцесуальним законодавством України діяльність суду у досудових стадіях кримінального процесу, що реалізується ним у визначеній процесуальній формі та спрямована на гарантування обгрунтованості та законності процесуальних дій та рішень суб'єктів розслідування і має на меті захист, а також охорону прав і свобод особи $[13$, с. 5$]$. 
М.А. Макаров дає визначення судового контролю в кримінальному процесі як діяльності слідчого судді на стадії досудового розслідування та під час екстрадиційної процедури зі здійснення в межах наданих йому повноважень в порядку, передбаченому КПК, метою якої є своєчасне забезпечення захисту та охорони прав, свобод та інтересів осіб у кримінальному провадженні [14, с. 78].

В.Я. Корсун та Л.Д. Удалова, розглядаючи судовий контроль на досудових стадіях кримінального процесу, здійснили влучне формулювання, визначивши його як особливий, самостійний вид судової діяльності, спрямований на забезпечення прав, свобод і законних інтересів особи, а також їх захист і відновлення у разі порушення органом дізнання, слідчим, прокурором [15, с. 68]. На нашу думку, крім звертання на цільову направленість, визначення судового контролю повинно містити вказівку щодо форм реалізації, яким чином і за допомогою чого здійснюється ця діяльність.

Особливості судового контролю виходячи 3 його цільової направленості досліджували інші вчені. Наприклад, В. В. Вовк також зазначає, що судовий контроль здійснюється у встановленому законом порядку та ініціюється шляхом внесення подання або скарги для перевірки законності й обгрунтованості обмежень конституційних прав і свобод громадян або встановлення доцільності таких обмежень [16, c. 163].

P.I. Тракало також наголошує, що судовий контроль у досудовому розслідуванні здійснюється 3 метою перевірки законності та обгрунтованості обмежень конституційних прав і свобод осіб у кримінальному провадженні. Судовим контролем у досудовому розслідуванні він називає здійснювану в установленому порядку діяльність слідчого судді, яка ініціюється стороною захисту, обвинувачення або за власною ініціативою слідчого судді $[17$, с. 5]. Проте науковець чомусь не враховує, що вказану діяльність можуть ініціювати не лише представники сторони обвинувачення й захисту, але й інші особи. Критикуючи вказане твердження, М. А. Макаров звертає увагу, що метою судового контролю $є$ не лише перевірка законності та обгрунтованості обмежень конституційних прав і свобод, але й контроль за дотриманням інших прав і законних інтересів осіб під час досудового розслідування [14, с. 126].

О.Г. Шило розглядає судовий контроль як перевірочну діяльність суду щодо розгляді скарг учасників кримінального провадження на дії чи рішення суб'єкта кримінального провадження [18, с. 153]. Судовий контроль з реалізацією перевірочної діяльності також пов'язують О.В. Капліна, І.С. Марочкін, Ю.М. Грошевий, В.Я. Тацій, А.Р. Туманянц [19, с. 13-14]. Функцією судового контролю останні називають засновану на законі кримінально-процесуальну діяльність слідчого судді як спеціально уповноваженого суб' єкта, здійснювану шляхом розгляду й вирішення клопотань і скарг сторін або потерпілого 3 метою охорони їх прав і свобод, якій притаманний як превентивний, так і правовідновлюючий характер [8, с. 115].

На думку І.В. Гловюк судовий контроль у кримінальному провадженні - це здійснювана у встановленому КПК порядку діяльність суду щодо розгляду та вирішення по суті скарг на дії чи бездіяльність суб'єктів (владних органів та посадових осіб) кримінального провадження [20, с. 11]. В.В. Косов визначає судовий контроль у кримінальному провадженні в якості функції судової влади, що полягає в реалізації слідчим суддею повноважень 3 перевірки рішень, дій чи бездіяльності органів досудового розслідування за скаргами сторін кримінального провадження [21, с. 7]. Водночас підкреслимо, що напрямки діяльності суду в кримінальному провадженні не можна характеризувати лише 3 позиції розгляду й вирішення скарг учасників кримінального процесу, а слід охоплювати ширшим за змістом поняттям «судовий контроль». 
Таким чином, наукова спільнота практично одностайно робить висновок про охоплення терміном «судовий контроль» діяльності суду щодо розгляду скарг на дії (бездіяльність) посадових осіб та органів досудового розслідування. Водночас думки вчених збігаються і в тому, що діяльності суду в досудовому провадженні притаманний неоднорідний характер [22, с. 176], а повноваження слідчого судді виходять за межі здійснення самого судового контролю, а функціональна спрямованість його діяльності, враховуючи наявні у нього повноваження, є поліфункціональною [20, с. 245; 23, с. 24].

Поняття судового контролю у кримінальному судочинстві слід формулювати крізь призму повноважень слідчого судді, виходячи зі змісту норм КПК, а також Рішення Конституційного Суду України від 30.06.2009 № 16-рп/2009, у якому визначена мета цього контролю, а саме «своєчасне забезпечення захисту та охорони прав і свобод людини і громадянина» [24]. Згідно п. 18 ч. 1 ст. 3 КПК слідчий суддя це суддя суду першої інстанції, до повноважень якого належить здійснення в порядку, передбаченому КПК, судового контролю за дотриманням прав, свобод та інтересів осіб у кримінальному провадженні, та у випадку, передбаченому ст. 247 КПК, - голова чи за його визначенням інший суддя відповідного апеляційного суду. Саме до компетенції слідчого судді (або голови) апеляційного суду належить здійснення судового контролю при проведенні НСРД, пов’язаних із використанням технічних засобів.

Діяльність слідчого судді щодо розгляду клопотань про здійснення правообмежувальних заходів (або судове санкціонування), у тому числі про надання дозволів на проведення НСРД, як і перевірка законності та виправданості дій, що в невідкладних випадках були проведені до постановлення ухвали слідчого судді в порядку ст. 250 КПК, повною мірою підпадає під категорію «судовий контроль». Ми можемо транспонувати вказане твердження і до судового контролю при проведенні НСРД, пов'язаних із використанням технічних засобів, адже практика свідчить про широке використання технічних засобів при проведенні НСРД, що обумовлено високим доказовим потенціалом отриманої за допомогою технічних засобів інформації.

Так, за результатами аналізу рішень Донецького апеляційного суду 3 питань здійснення судового контролю при проведенні НСРД виявлено, що в більшості випадків під час проведення НСРД для отримання процесуально значущої інформації в той чи інший спосіб застосовувались технічні засоби. У подальшому отримана інформація слугувала доказовою базою в кримінальних провадженнях. Проте слід констатувати наявність непоодиноких випадків порушень з боку суб'єктів проведення НСРД, обумовлених, у першу чергу, існуючою неузгодженістю правових норм, відсутністю дієвого механізму отримання й реалізації отриманої за допомогою технічних засобів інформації, який би гарантував виключну законність вказаної діяльності.

Розглядаючи питання щодо сутності судового контролю при проведенні НСРД, пов'язаних із використанням технічних засобів, слід виділити супутні особливості та обставини, які найчастіше виникають у діяльності слідчого судді. Складність роботи щодо судового контролю при проведенні НСРД, пов'язаних із використанням технічних засобів, полягає в забезпеченні балансу між діями, спрямованими на захист особи, суспільства й держави від злочинів, i, разом із тим, дотриманням прав підозрюваного, обвинуваченого, засудженого. Адже втручання в приватне життя людини, навіть тієї, яка притягується до кримінальної відповідальності, завжди повинне бути мінімально необхідним для досягнення мети цього втручання. При проведенні НСРД, пов'язаних із використанням технічних засобів, ефективний судовий контроль має бути спрямований на недопущення незаконного обмеження 
конституційних прав учасників кримінальної процесуальної діяльності, а в разі необхідності на швидке й ефективне їх відновлення.

3 інформаційної точки зору НСРД, пов'язані з використанням технічних засобів, мають на меті за допомогою науково обгрунтованих технічних засобів і прийомів, законно отримувати інформацію про злочинну діяльність однієї чи декількох осіб, а також створювати умови, що сприяють виділенню з усієї сукупності відомостей, які більш повно відображують сутність процесів, що відбуваються. Застосування технічних засобів не повинно суперечити принципам правомірності, суворого цільового застосування, наявності фактичних підстав, етичності та встановленого порядку документального оформлення.

Можна виділити наступні ознаки кримінально-процесуального судового контролю при проведенні НСРД, пов'язаних із використанням технічних засобів: 1) це чітко регламентована КПК кримінально-процесуальна діяльність суду, сутність якої полягає в перевірці та оцінці законності й обгрунтованості проведення НСРД, пов'язаних із використанням технічних засобів; 2) ця діяльність не спрямована на врегулювання правового спору (конфлікту) сторін по суті; 3) предмет судового контролю та межі його здійснення з самого початку обмежені волею закону або суб'єктивною волею сторін; 4) метою судового контролю при проведенні НСРД, пов'язаних із використанням технічних засобів, є захист конституційних прав, свобод і законних інтересів громадян, (можливе) відновлення цих прав за скаргою заінтересованих осіб; 5) ініціатором щодо реалізації будь-якої форми судового контролю йде не від суду, а від заінтересованих у вирішенні справи по суті суб'єкти кримінального судочинства або інші особи, залучені до кримінального провадження. Поза цієї ініціативи контроль неможливий; 6) результатом судового контролю при проведенні НСРД, пов'язаних із використанням технічних засобів, $\epsilon$ винесення загальнообовязкового, забезпеченого державним примусом судового акту (рішення).

Висновки. Враховуючи вищенаведене, слід зробити висновок, що судовий контроль - це окрема функція суду на досудових стадіях кримінального процесу поряд із дозвільною функцією та функцією застосування заходів кримінально-процесуального примусу. Здійснення судового контролю при проведенні НСРД, пов'язаних із використанням технічних засобів, належить до компетенції слідчого судді (або голови) апеляційного суду. Діяльність слідчого судді щодо розгляду клопотань про здійснення правообмежувальних заходів (або судове санкціонування), у тому числі про надання дозволів на проведення НСРД, як і перевірка законності та виправданості дій, що в невідкладних випадках були проведені до постановлення ухвали слідчого судді, повною мірою підпадає під категорію «судовий контроль».

Значення судового контролю полягає в тому, що завдяки діяльності слідчого судді забезпечуються невідкладним судовим захистом права, свободи та інтереси учасників кримінального провадження, а також створюються належні умови для реалізації принципу змагальності в кримінальному процесі.

Судовий контроль при проведенні НСРД, пов'язаних із використанням технічних засобів, можна визначити як особливий самостійний вид судової діяльності, спрямований на забезпечення прав, свобод і законних інтересів особи, а також їх захист і відновлення у разі їх порушення суб'єктом кримінального провадження (сутність контролю), що здійснюється 3 метою перевірки законності та обгрунтованості обмежень конституційних прав і свобод осіб при проведенні НСРД, пов'язаних із використанням технічних засобів, або 3 метою встановлення доцільності таких обмежень, ініціюється стороною захисту (шляхом внесення подання, клопотання або скарги на рішення, дії чи бездіяльність суб’єкта проведення НСРД), обвинувачення 
(шляхом запиту дозволу щодо проведення НСРД, пов'язаних із використанням технічних засобів, або оскарження відмови у наданні дозволу) або за власною ініціативою слідчого судді (або голови апеляційного суду), та передбачає обов'язкове винесення забезпеченого державним примусом судового акту.

\section{Список використаної літератури}

1. Гаращук В. М. Теоретико-правові проблеми контролю та нагляду у державному управлінні : дис. д-ра юрид. наук : 12.00.07 / НЮА України ім. Я. Мудрого. Харків, 2003. 413 c.; Harashchuk V. M. Teoretyko-pravovi problemy kontroliu ta nahliadu u derzhavnomu upravlinni : dys. d-ra yuryd. nauk : 12.00.07 / NIuA Ukrainy im. Ya. Mudroho. Kharkiv, 2003. $413 \mathrm{~s}$.

2. Багрій М. В. Судовий контроль за проведенням негласних слідчих (розшукових) дій: окремі аспекти // Науковий вісник Ужгородського націон. ун-ту; серія Право. Вип. 35. Ч. 1. Т. 3. Ужгород, 2015. С. 86-89; Bahrii М. V. Sudovyi kontrol za provedenniam nehlasnykh slidchykh (rozshukovykh) dii: okremi aspekty // Naukovyi visnyk Uzhhorodskoho natsion. un-tu; seriia Pravo. Vyp. 35. Ch. 1. T. 3. Uzhhorod, 2015. S. 86-89.

3. Пєший Д.А. Забезпечення законності у досудовому кримінальному провадженні: [моногр.]. К.: Видавн. центр «Кафедра», 2015. 149 с.; Pieshyi D.A. Zabezpechennia zakonnosti u dosudovomu kryminalnomu provadzhenni: [monohr.]. K.: Vydavn. tsentr «Kafedra», 2015. 149 s.

4. Проблеми забезпечення ефективності діяльності органів кримінального переслідування в Україні: [моногр.] / кол. авт.; за ред. В.І. Борисова, В.С. Зеленецького. X.: Право, 2010. 400 с.; Problemy zabezpechennia efektyvnosti diialnosti orhaniv kryminalnoho peresliduvannia v Ukraini: [monohr.] / kol. avt.; za red. V.I. Borysova, V.S. Zelenetskoho. Kh.: Pravo, 2010. 400 s.

5. Туманянц А.P. Контрольні функції суду у сфері кримінального судочинства. Харків: Основа, 2000. 108 с.; Tumaniants A.R. Kontrolni funktsii sudu u sferi kryminalnoho sudochynstva. Kharkiv: Osnova, 2000. 108 s.

6. Гузела М. Контроль за законністю дій i рішень органів досудового розслідування як самостійна функція суду. Вісник Львівського університету. Серія юридична. 2004. Вип.39. С.443-449; Huzela M. Kontrol za zakonnistiu dii i rishen orhaniv dosudovoho rozsliduvannia yak samostiina funktsiia sudu. Visnyk Lvivskoho universytetu. Seriia yurydychna. 2004. Vyp.39. S.443-449.

7. Гловюк І.В. Судова діяльність у досудовому провадженні: автореф. дис. канд. юрид. наук ; спец. 12.00.09. Одеса, 2008. 20 с.; Hloviuk I.V. Sudova diialnist u dosudovomu provadzhenni: avtoref. dys. kand. yuryd. nauk ; spets. 12.00.09. Odesa, 2008. 20 s.

8. Кримінальний процес: підручник / [Ю. М. Грошевий, В. Я. Тацій, А. Р. Туманянц та ін.]; за ред. В. Я. Тація, Ю. М. Грошевого, О. В. Капліної, О. Г. Шило. Х.: Право, 2013. 824 c.; Kryminalnyi protses: pidruchnyk / [Iu. M. Hroshevyi, V. Ya. Tatsii, A. R. Tumaniants ta in.]; za red. V. Ya. Tatsiia, Yu. M. Hroshevoho, O. V. Kaplinoi, O. H. Shylo. Kh.: Pravo, 2013. 824 s.

9. Полюхович О. І. Співвідношення функції правосуддя та судового контролю при здійсненні негласних слідчих (розшукових) дій: питання теорії та практики / O. I. Полюхович // Публічне право. 2016. № 2. С. 166-173; Poliukhovych O. I. Spivvidnoshennia funktsii pravosuddia ta sudovoho kontroliu pry zdiisnenni nehlasnykh slidchykh (rozshukovykh) dii: pytannia teorii ta praktyky / O. I. Poliukhovych // Publichne pravo. 2016. № 2. S. 166-173.

10. Химичева О. В. Концептуальные основы процессуального контроля и надзора на досудебных стадиях уголовного судопроизводства : дис. д-ра юрид. наук; спец 
12.00.09. О.В. Химичева. М., 2004. 402 с.; Khymycheva O. V. Kontseptualnie osnovi protsessualnoho kontrolia i nadzora na dosudebnikh stadyiakh uholovnoho sudoproyzvodstva : dys. d-ra yuryd. nauk; spets 12.00.09. O.V. Khymycheva. M., 2004. 402 s.

11. Кондратьєв О.В. Організаційно-правові проблеми судового контролю: дис. канд. юрид. наук: спец. 12.00.10. Харків, 2005. 191 с.; Kondratiev O.V. Orhanizatsiinopravovi problemy sudovoho kontroliu: dys. kand. yuryd. nauk: spets. 12.00.10. Kharkiv, 2005. $191 \mathrm{~s}$.

12. Шавкун М.Г. Процесуальний контроль органів державної влади на досудових стадіях кримінального процесу: автореф. дис. канд. юрид. наук: спец. 12.00.09. К., 2010. 20 c.; Shavkun M.H. Protsesualnyi kontrol orhaniv derzhavnoi vlady na dosudovykh stadiiakh kryminalnoho protsesu: avtoref. dys. kand. yuryd. nauk: spets. 12.00.09. K., 2010. $20 \mathrm{s.}$

13. Кисленко Д.П. Судовий контроль під час розслідування злочинів: автореф. дис. канд. юрид. наук: спец. 12.00.09. К., 2012. 16 с.; Kyslenko D.P. Sudovyi kontrol pid chas rozsliduvannia zlochyniv: avtoref. dys. kand. yuryd. nauk: spets. 12.00.09. K., 2012. 16s.

14. Макаров М. А. Судовий контроль у кримінальному процесі: теоретичні та правові основи : дис . д-ра юрид. наук : спец. 12.00.09 / М. А. Макаров; НАВС України. Київ, 2018. 495 с.; Makarov M. A. Sudovyi kontrol u kryminalnomu protsesi: teoretychni ta pravovi osnovy : dys . d-ra yuryd. nauk : spets. 12.00 .09 / M. A. Makarov; NAVS Ukrainy. Kyiv, 2018. $495 \mathrm{~s}$.

15. Удалова Л.Д. Суд як суб'єкт кримінально-процесуального доказування : монографія // Л.Д. Удалова, В.Я. Корсун. К: Видавничий дім «Скіф». 2012. 168 с.; Udalova L.D. Sud yak subiekt kryminalno-protsesualnoho dokazuvannia : monohrafiia // L.D. Udalova, V.Ia. Korsun. K: Vydavnychyi dim «Skif». 2012. 168 s.

16. Вовк В. В. Кримінально-процесуальна діяльність органів безпеки : дис. канд. юрид. наук : 12.00.09 / В. В. Вовк; НАВС Украъни. К., 2011. 183 с.; Vovk V. V. Kryminalno-protsesualna diialnist orhaniv bezpeky : dys. kand. yuryd. nauk : 12.00 .09 / V. V. Vovk; NAVS Ukraъny. K., 2011. 183 c.

17. Тракало P.I. Судовий контроль за дотриманням права на повагу до приватного життя: автореф. дис. канд. юрид. наук: спец. 12.00 .09 ; Акад. адвокатури України / Роман Ігорович Тракало. К., 2014. 20 c.; Trakalo R.I. Sudovyi kontrol za dotrymanniam prava na povahu do pryvatnoho zhyttia: avtoref. dys. kand. yuryd. nauk: spets. 12.00.09 ; Akad. advokatury Ukrainy / Roman Ihorovych Trakalo. K., 2014. 20 s.

18. Шило О. Г. Завдання й функції суду в кримінальному судочинстві України. Проблеми законності. Респ. міжвідом. наук. зб. / Відп. ред. В.Я. Тацій. Х.: Нац. юрид. акад. України, 2008. Вип.94. С.148-157; Shylo О. Н. Zavdannia y funktsii sudu v kryminalnomu sudochynstvi Ukrainy. Problemy zakonnosti. Resp. mizhvidom. nauk. zb. / Vidp. red. V.Ia. Tatsii. Kh.: Nats. yuryd. akad. Ukrainy, 2008. Vyp.94. S.148-157.

19. Грошевий Ю.М. Органи судової влади в Україні / Ю.М. Грошевий, І.С. Марочкін. К.: Ін Юре, 1997. 20 с.; Hroshevyi Yu.M. Orhany sudovoi vlady v Ukraini / Yu.M. Hroshevyi, I.Ie. Marochkin. K.: In Yure, 1997. 20 s.

20. Гловюк I.В. Кримінально-процесуальні функції: теорія, методологія та практика реалізації на основі положень Кримінального процесуального кодексу України 2012 р. : монографія. Одеса : Юрид. літ., 2015. 712 с.; Hloviuk I.V. Kryminalnoprotsesualni funktsii: teoriia, metodolohiia ta praktyka realizatsii na osnovi polozhen Kryminalnoho protsesualnoho kodeksu Ukrainy 2012 r. : monohrafiia. Odesa : Yuryd. lit., 2015. $712 \mathrm{~s}$.

21. Косов В.В. Суб’єкти судового-контрольного провадження на досудових стадіях кримінального процесу: автореф. дис. канд. юрид. наук: спец. 12.00.09. Нац. ун-т «Одеська юридична академія». Одеса, 2012. 20 c.; Kosov V.V. Subiekty sudovoho-kontrolnoho 
provadzhennia na dosudovykh stadiiakh kryminalnoho protsesu: avtoref. dys. kand. yuryd. nauk: spets. 12.00.09. Nats. un-t «Odeska yurydychna akademiia». Odesa, 2012. 20 s.

22. Шило О.Г. Теоретичні основи та практика реалізації конституційного права людини і громадянина на судовий захист у досудовому провадженні в кримінальному процесі України : дис. д-ра юрид. наук : 12.00.09 / Нац. ун-т «Юрид. акад. України ім. Я. Мудрого. Харків, 2011. 479 с.; Shylo O.H. Teoretychni osnovy ta praktyka realizatsii konstytutsiinoho prava liudyny i hromadianyna na sudovyi zakhyst u dosudovomu provadzhenni v kryminalnomu protsesi Ukrainy : dys. d-ra yuryd. nauk : 12.00.09 / Nats. un-t «Iuryd. akad. Ukrainy im. Ya. Mudroho. Kharkiv, 2011. 479 s.

23. Полюхович O.I. Судовий контроль при проведенні негласних слідчих (розшукових) дій : дис. канд. юрид. наук : 12.00 .09 / О. І. Полюхович ; кер. роботи О. Г. Шило ; Нац. юрид. ун-т ім. Ярослава Мудрого. Харків, 2017. 231 с.; Poliukhovych O.I. Sudovyi kontrol pry provedenni nehlasnykh slidchykh (rozshukovykh) dii : dys. kand. yuryd. nauk : 12.00.09 / O. I. Poliukhovych ; ker. roboty O. H. Shylo ; Nats. yuryd. un-t im. Yaroslava Mudroho. Kharkiv, 2017.231 s.

24. Рішення Конституційного Суду України від 30.06.2009 № 16-рп/2009. Справа № 1-17/2009. URL: http://ccu.gov.ua/sites/default/files/ndf/16-rp/2009.doc (дата звернення: 11.11.2019); Rishennia Konstytutsiinoho Sudu Ukrainy vid 30.06.2009 № 16-rp/2009. Sprava № 1-17/2009. URL: http:// ccu.gov.ua/sites/default/files/ndf/16-rp/2009.doc (data zvernennia: 11.11.2019).

\section{O. Lisovyi \\ THE CONCEPT AND ESSENCE OF JUDICIAL CONTROL WHEN CARRYING OUT THE INVESTIGATIVE (SEARCH) ACTIONS RELATED TO THE USE OF TECHNICAL MEANS}

The article deals with the essence of judicial control when conducting unspoken investigative (search) actions related to the use of technical means. Through the prism of such important functions of the court as the consideration of appeals against decisions, actions (inaction) of officials and pre-trial investigation bodies, granting procedural permits related to the justified restriction of citizens' rights, the key features of the category "judicial control" have been identified. The related set of criminal procedural definitions provides the author's definition of judicial control in conducting unspoken investigative (investigative) actions related to the use of technical means.

Keywords: criminal proceedings, unspoken investigators (investigative actions), investigating judge, court, judicial control, technical means.

Стаття надійшла до редакції 04.11.2019 р. 